\title{
The Analytic Domain of Multiple- Intelligence and Its Relation to English Objective Test
}

\author{
Baan Jafar Sadiq ${ }^{1}$ \\ ${ }^{1}$ College of Physical Education and Science Sports for Women, Baghdad University, Baghdad, Iraq \\ Correspondence: Baan Jafar Sadiq, College of Physical Education and Science Sports for Women, Baghdad \\ University, Baghdad, Iraq.
}

Received: March 15, 2018 Accepted: April 17, 2019 Online Published: April 19, 2019

doi: 10.5539/elt.v12n5p161 URL: https://doi.org/10.5539/elt.v12n5p161

\begin{abstract}
The current research aims at identifying the analytic domain of multiple -intelligence and English objective test. The research is trying to answer that if there is a correlation between the analytic domain of multipleintelligence and the English objective tests. Thus, the research has adopted a close questionnaire for diagnosing analytic domain (logical, rhythmic, and naturalistic) of multiple- intelligence of Iraqi students at Baghdad University, and an objective English test to achieve the aim of the research. Nine colleges at Baghdad University are randomly chosen to represent the sample of the research which is 511 students. The results of the research have shown that there are weak significant correlation between the analytic domain of multiple intelligent and the objective English test. Thus, from the results of the research Baghdad University could modify the objective tests with alternative ones that based on students' ability and intelligence not guessing tests. Continuous long-term assessment, untimed, free- response format, individualized test and creative answers based on multiple- intelligence are recommended.
\end{abstract}

Keywords: multiple- intelligence, analytic domain, objective test, English language teaching

\section{Introduction}

\subsection{The Problem of the Research}

Although Gardner's MI theory is proposed for many years teachers are less aware of using and applying MI theory in the field of teaching and assessing foreign language. The tester needs to set the problem that can be solved in context rather than to memorize set of rules and grammar (Boonma, 2014). English teachers as well as university instructors are concerned about the tests and how are suited the students' ability. Also, the shifting from the teacher centered into learners centered methods paved the way to investigate scientifically other ways of teaching and testing. There is a trend to supplement traditional test designs with alternative tests that are more authentic in their elicitation of meaningful communication which is untimed, open-ended, creative answer, oriented to process, continuous long-term assessment and individualized feedback and wash back (Brown, 2004). Learning a foreign language is a difficult process. It does not involve learning skills but it involves the learner's adoption of new social and cultural behaviors, and has a significant impact on the social nature (Williams, 1994). Objective tests give the probability of the students responding correctly to an item without being sure of facts. Guessing could be a strategy for low ability students to get more marks (Obinne, 2012). Baghdad University policy uses the traditional way for testing students although, all Baghdad University' Colleges use "New Headway Plus" as a series textbooks in teaching English foreign language but they are still adopting the traditional methods in testing.

The problem of the research depends on the method of testing and assessing English language which is being followed at Baghdad University. English teachers have adopted traditional test which focused on memorizing English rules and terms neglecting students' intelligence. Objective tests are not suitable to measure students' achievement because low students' abilities could achieve high marks by guessing. So, Many English teachers and instructors in higher education pay attention to knowledge rather the students' intelligence in the test. Thus, the significance of this research is to answer the question "is there correlation between analytic domain of multiple-intelligence and the objective English test?" 


\subsection{The Importance of the Research}

The following are the importance of the research:

1) It might contribute to the way that teachers and instructors constructing their English test.

2) Multiple intelligence research raises teachers' awareness of the best ways in the development of course materials, teaching methods and testing which are of paramount importance in the learning/teaching process.

3) It provides information to be taken into consideration by policy makers, language-planners, textbook developers, language instructors, as well as the test designers. Hopefully, the present research will provide us with opportunities to look differently at the curriculum, instruction and testing.

4) It helps teachers to design a courses and test in that they can awaken all kinds of intelligence in their students and take advantage of a variety of games, stories, music, images as well as different tools and materials intended to mix all kinds of intelligence. As a result, teachers' creativity will be strengthened and it will free them from relying just on traditional test and encourage them to design a syllabus and tests appropriate at the level of their students' intelligence.

5) This research may spread awareness among EFL teachers on the MI theory and its implications in education in general and in ELT field in particular and hold training sessions for teachers on the MI theory and its educational implications.

6) It is expected that this research would open a new horizon for the instructors to adopt the student centered teaching and relinquish the traditional teacher centered teaching. Teachers implement new techniques and students understand lesson goals and objectives, value communicative tasks and activities, generate topics and choose materials, work cooperatively, and identify their own learning strategies and styles (Naqeeb \& Awad, 2011).

7. The results of this research may help curriculum developers and testers in Iraq choose more meaningful activities based MI theories and tasks that meet many different intelligence domains, motivation orientations and objective English test.

8. The current research reveal to alternative types of test which is more authentic and timeless which might be suitable for students' multiple-intelligence.

\subsection{Relevant Studies}

There are many studies which have tackled multiple -intelligence as the following:

1) Madkour and Mohamamed (2016). The study is quasi- experimental one investigated the effect of MI as integrated abilities for English teaching at higher education. The aim of the research is to examine the impact of students' MI profiles on students' motivation and proficiency. The research prepared questionnaire with a Likert scale to identify students' MI. The control group is taught according traditional instructions relied on memorizing grammatical rules while the experimental group is taught according students' MI profiles. The results have showed ineffective teaching that relied on memorizing language rules. The study finds a statistical relation between MI and students' motivation and language proficiency (Madkour \& Mohamamed, 2016). The previous study is identified the relation between multiple intelligences domains and students' language proficiency but the current research identifies the relation between Analytic Domain of MI and English objective test.

2) Abidi et al. (2013). The study aims to investigate the effect of teaching strategy based on multiple intelligences on students' achievement. Therefore, two groups have been chosen to fillfull the aim of this study. This study has concluded that if students are offered a variety of learning experiences, they will become actively engaged and invested in learning process. Therefore, the students who taught through multiple intelligence instructions were achieved higher score than the traditional instruction (Abidi et al., 2013). The previous study was experimental one but the current research is descriptive research. The previous study was investigated students' achievement while the current research focuses on students' achievements in objective test.

3) Silja, Kallenbach and Viens, Juli (2001) the study has many questions one of them is "how MI theory can support instruction and assessment with adult". It has used instructions, activities, interviews, case studies, profiles and observations, and weekly assessment are based on MI theory. The findings of the results have shown impact to MI activities, and these activities shape students' reaction and participation as well achievement in ESOL (Silja, Kallenbach, \& Viens, 2001). The previous study has assessed the students' intelligences and this is similar with the current research but the current research is focuses on students' Analytic Domain of MI. There are three points in line with the current research. Firstly both use descriptive method, secondly; both researches 
tackld with adults. Thirdly, both researches assess students' intelligence.

furtherrmore, all the previous studies have small samples Abidi et al. (2016) is 40 students, Silja and Viens (2001) is 10 students, and Madkour and Mohamamed (2016) is 108 while the current research has 511 Iraqi students from 9 colleges at Baghdad University. All the previous studies have investigated MI but this research has focused on Analytic Domain of MI and objective test not assessment or achievement tests.

\subsection{The Question of the Research}

The current research is trying to reveal the connection between the analytic domain of multiple- intelligence and English objective test by answering the question "Is there any relation between the analytic domain of multi intelligence of Iraqi students at Baghdad University and English objective test?"

\section{Methods of the Research}

The research has followed descriptive method and it has adopted some procedures to fulfill the aim of the research. It has applied a close questionnaire for diagnosing the Analytic Domain of Multiple -intelligence and English objective test to collect data from Iraqi students at Baghdad University. The following are the operational definitions of the variables:

1) Multiple Intelligence is a type of intelligences each person possesses to understand, store and retrieve information which can either be done independently or together. Razmjoo (2008), Richards and Schmidt (2002), Richards and Rodgers (2001).

2) The Analytic Domain consists of the logical, musical and naturalistic intelligences. These intelligences are heuristic processes in nature. They are considered analytic because they promote analysis of knowledge that is presented to the learner and incorporating data into existing schema (McKenzie, 2002).

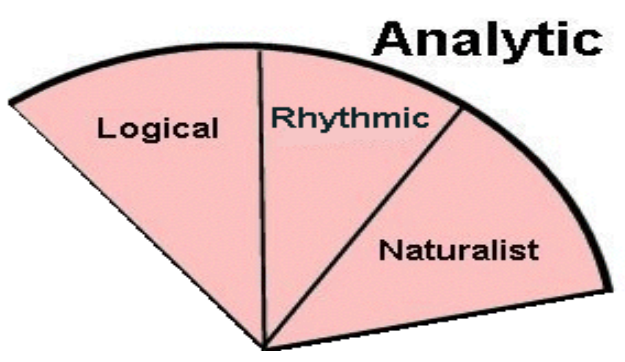

Figure 1. The analytic domain

3) Logical-mathematical consists of items that measure a person's perceptions of both their mathematical ability and logical thinking skills. The key abilities of Logical-Mathematical Intelligence are: a) appreciating abstract relations and b) facility in the use of numbers (Tirri \& Nokelainen, 2011).

4) Musical / Rhythmic Intelligence is the capacity to perceive, discriminate, transform, and express musical forms. This intelligence includes sensitivity to the rhythm, pitch or melody, and timbre or tone color of a musical piece. People with Musical intelligence have a figural or "top-down" understanding of music (global, intuitive), a formal or "bottom-up" understanding (analytic, technical), or both (Armstrong, 2009).

5) Naturalistic Intelligence: People with naturalistic intelligence, have an expertise in recognizing and classifying the numerous species - the flora and fauna found in an individual's environment. They have ecological sensitivity to other natural phenomena (e.g., cloud formations, mountains, etc.) (Armstrong, 2009).

6) Objective Test is a test that can be scored objectively without personal judgment i.e true-false, multiple-choice items ect. (Richards \& Schmidt, 2002).

\subsection{Analytic Domain of Multiple- Intelligence Questionnaire}

The research has applied a questionnaire to diagnose the analytic domain of multiple intelligences of Iraqi students at Baghdad University. It is based on Howard Gardner's Multiple Intelligence Test (2007). But the current research has chosen the Analytic Domain of the test which includes three categories: logical/ mathematic, musical/ rhythmic, and naturalistic. Each category consists of 4questions items. Each item represents certain aspect of the student's thinking and feeling, it is followed by a five- point Likert scale ranging from (1) never, (2) rarely, (3) sometimes, (4) often, to (5) always. The questions are translated into Arabic language so to collect 
right responses especially English is a foreign language taught in Iraq

\subsubsection{Validity of the Questionnaire}

The close questionnaire has been given to 5 jury members in the field of Psychology and ELT to ensure the face and content validity. The percentage of the agreement of the questionnaire is $(100 \%)$ which is considered high agreement percentage; therefor, the questionnaire has been adopted without any modification.

\subsubsection{Reliability of the Questionnaire}

It has been used the Cronbach's Alpha to measure the reliability of analytic domain of multiple- intelligence questionnaire. The total score for the three categories is 0.62 which indicates good reliability.

\subsection{English Objective Test}

The test has included six questions each consisted five items. The first question is true and false sentences depended on reading comprehension. The second question is multiple choice with four options, and the third one is matching question. While the fourth question is ticking the correct sentence each item has two options depending on the grammar, the fifth one is putting the words in correct list (place- job- food). Finally, the last question is re-order the words to make questions. English objective test's questions are selected from "New Headway Plus, intermediate level".

\subsubsection{Validity of Objective Test}

The test has given to the same jury members to insure it face and content validly. The validity of the test is (92\%) which indicates high percentage score. Thus, the test has adopted in the final version test.

\subsubsection{Reliability of Objective Test}

The test has given to 30 students as a pilot study to reveal the difficulty and the time require. It has been used test re-test for reliability. The score has shown good reliability (100\%). Also, reliability statistics score of Cronbach's Alpha is 0.666 of all the six questions. Thus, it indicates a good reliability, the test has adopted without any modification.

\subsection{Sampling Procedures}

The population of the research is Iraqi students at Baghdad University which are 6211. The sample of the research has been chosen randomly as a cluster samples according to the Colleges of Baghdad University (Nursing College- Sciences College- Education College- Physical Education and Science Sport for WomenAgriculture Engineering College- Arts College- Islamic Sciences College- Languages College- Education College- Sciences Education College). The sample of the research is $20 \%$ of the population of the research. The age of the sample is between (19-23). Many students' forms are excluded because they are above the average age. Also, many students' forms are voided because they are not complete either the test or the questionnaire. Thus, the final size of the sample is 511 Iraqi students at Baghdad University.

\section{Results}

The results of the research have analyzed according Statistical Package for the Social Science Software (SPSS) by using correlation.

\subsection{Statistics and Data Analysis}

The results of the research have analyzed in order to determine whether there is any statistical significant correlation coefficient among the three categories of Analytic domain of multiple intelligence (Logical, Rhythmic, and Naturalistic) and Iraqi students' English objective test. Spearman's Correlations coefficient is used. Brown (2005: 285) defined correlation coefficient as a numerical value represent the relation of two variables which range from $(+1.0$ to -1.0$)$. See Table (1):

Table 1. Correlation of types of multiple intelligence and English objective test

\begin{tabular}{llllllll}
\hline Correlations & \multicolumn{1}{l}{} & & \\
\hline $\begin{array}{l}\text { Types of multiple } \\
\text { intelligence }\end{array}$ & $\begin{array}{l}\text { true and choose the } \\
\text { false items } \\
\text { correct answer }\end{array}$ & $\begin{array}{l}\text { match } \\
\text { items } \\
\text { in correct list }\end{array}$ & $\begin{array}{l}\text { put the words } \\
\text { correct } \\
\text { answer }\end{array}$ & $\begin{array}{l}\text { re-order the } \\
\text { words }\end{array}$ \\
\hline $\begin{array}{l}\text { logical } \\
\text { mathematic type }\end{array}$ & $/$ & .034 & .024 & .067 & .043 & .022 & .030 \\
\hline
\end{tabular}




\begin{tabular}{lllllll}
\hline Musical type & -.056 & $.166^{* *}$ & $.236^{* *}$ & $.187^{* *}$ & $.145^{* *}$ & $.376^{* *}$ \\
naturalistic type & -.017 & -.002 & -.011 & .067 & -.051 & -.001 \\
Analytic domain & -.008 & .005 & .005 & .006 & $.107^{*}$ & 0.21 \\
\hline
\end{tabular}

**. Correlation is significant at the 0.01 level (2-tailed).

Table 1 shows that there is positive weak statistical significant correlation between the logical category and true and false items is 0.034 , choose the correct answer is 0.024 , match items is 0.067 , put the words in the correct list is 0.043 , tick the correct answer is 0.022 , and re- order the words is 0.03 . Musical category of MI obtains negative weak correlation between true and false items of the objective test which is -0.056 , choose the correct answer is 0.166 which indicates significant correlation at the level 0.01 , match items is 0.236 which indicates significant correlation between musical category and the match items, put the words in correct list question is 0.187 this obtains that there is positive correlation between them, tick the correct answer is 0.145 which is also significant correlation, and re- order the words is 0.376 which is significant correlation at the level 0.01. Finally, the naturalistict category with true false score is -0.017 which indicates negative weak correlation between naturalist category of MI and true false items, choose the correct answer score is -0.002 which indicates negative weak significant correlation between the naturalist and choose the correct answer, match items score is -0.011 which obtains that there is positive weak correlation, put the words in correct list score is 0.067 which is positive weak correlation, tick the correct answer score is -0.51 which is negative weak correlation, and re-order the words score is -0.001 which is negative weak correlation between Naturalist category and re-order the words. Finally, the Analytic domain of MI scores show that there are weak correlation between true false items which is -0.008 , choose the correct answer is 0.005 , match items score is 0.005 , put the words in correct list is 0.006 , tick the correct answer score is significant correlation at the level 0.01 , and re-order the words score is 0.21 .

Based on the results obtain from the Table 1, it can be said that there is weak significant correlation between the Analytic domain of MI and true false items, choose the correct answer, match items, put the words in correct list, and re- order the words. But the Analytic domain of MI shows significant correlation in tick the correct answer.

\section{Discussion, Conclusions, and Recommendations}

According to the results obtained, it can be said the following:

(a) Most objective test items are a "dichotomous choice" (Richards \& Schmidt, 2002). This is clear in the score obtains between tick the correct answer and Analytic domain of MI and the significant correlation between them. The guessing item of objective test is not a valid to measure students' achievement and ability. This result is in agreement with Obinne (2012) guessing could be a strategy by students to earn marks without being sure of the knowledge. Objective items have attracted students with low ability for guessing (Obinne, 2012).

(b) English test should be proportional with method of teaching. Baghdad University has used modern textbook in teaching EFL but it supplied English teachers with objective test. The test is considered suitable when it measures exactly what is supposed to measure.

(c) Objective test has failed to meet students' analytic domain of multiple- intelligence. Thus, objective test has not fitted students' analytic domain of multiple- intelligence. It is lined with Madkour and Masounmeh (2016), Abidi et al. (2013), and Silja and Viens (2001).

(d) Fixed question time and options of objective tests do not encourage students creativity, ability to solve problem, working together on the same project, ability of analysis and discussion...ect. This is in agreement with Silja and Viens (2001). The current finding completely agrees with Brown (2004) who informed that the time requires test and assessment should not be fixed specially with English subject. Although the objective test focuses on the right answer, covers a wide information, corrects answers objectively but objective test does not reflect the creativity of the students as well interactive performance, discussion, opinion, hypothesis which is important rule in learner-center approach in teaching EFL.

(e) Objectives test encourage students memorize set of rules and terms to achieve the success in the test while teaching EFL goal to enable the students to reach the proficiency. This is impossible by using the traditional method of teaching English; teacher should know students' intelligence and try to develop their achievement. The current research alignments with Madkour and Mohamamed (2016) the study concluded that memorizing language rules do not give language proficiency while teaching by MI instructions lead to students' proficiency. These findings are relevant to Abidi et al. (2013) that engaging with MI activities have effected students' achievement. Also, the results of the research Silja, and Viens (2001) identifying students' strongest intelligence 
guide the learning process for better achievement. The researchers prepared many assessments according students' intelligence with activities based on MI theory. Therefore, the students have improved their intelligence as well the achievement.

(f) The policy of Baghdad University which has forced English teachers in all the colleges adopts "New Headway Plus" as a syllabus with fixed tests depend on objective scoring items disregard the specializations i.e (student at College of Physical Education student is different from student at Science College, College of arts, College of Languages ect...). The significant weak correlation between analytic domain of multiple- intelligence and objective test indicates that there is no connection between them. These findings of the results go in line with Madkour and Masounmeh (2016), Abidi et al. (2013), and Silja and Viens (2001). Thus, the English test should reflect the intelligence of the students. University of Baghdad might change the policy of the Iraqi English assessment.

(g) English test is the starting point not the last one as many English teacher thought. The test is the beginning of developing the students' ability. Students' fear from English test was an obstacle facing the current research. Therefore, a lot of forms were excluded from the sample because of this issue. The finding of the research agrees with Madkour and Mohamamed (2016) the study mentioned that MI assessment guide the learning process.

It is concluded from the results of the research that the objective test is not appropriate for students' achievement because it has guessing items. Objective test could encourage students' memorization, furthermore, objective test do not reflected students' abilities and intelligence. So, it is important to try alternative test which suite the modern textbook adopted by Baghdad University. Objective test and written test is not the only way for assessing students' achievement. English teachers and instructors could apply many other tests but they are faced by the policy of education in Iraq and Baghdad University. English teachers and test designers should construct their materials and tests according learner-centered approach. Baghdad University could give freedom for English teachers for creativity and respect College's specializations. But Baghdad University duty is to provide professional development courses for the staff members of English language teaching.

The research has suggested that other researches might tackle with alternative assessment with the multipleintelligence. Also, it might investigate other types of multiple-intelligence and objective test.

\section{Acknowledgements}

I would like to express my gratitude to all who help me to accomplish this work. Special thanks due to my precious treasures children Zaead, Samar and Yehea my lovely Down syndrome child who inspired me with studies as I was working to solve his difficulties.

\section{References}

Abdi, A., Laei, S., \& Ahmadyan, H. (2013). The Effect of Teaching Strategy Based on Multiple Intelligences on Students' Academic Achievement in Science Course. University Journal of Education Research, 1(4). https://doi.org.10.13189/ujer.2013.01040

Arnold, J., \& Fonseca, M. (2004). Multiple Intelligence Theory and Foreign Language Learning: A Brain-Based Perspective. International Journal of English Studies (IJES), 4(1), 119-136.

Armstrong, T. (2003). The Multiple Intelligences of Reading and Writing Making the Words Come Alive. Alexandria, VA: ASCD.

Armstrong, T. (2009). Multiple Intelligence in the Classroom. Alexandria, Virginia USA.

Boonma, M. (2014). Why is an Application of Multiple Intelligences Theory Important for Language Learning and Teaching Speaking Ability? Advances in Language and Literary Studies, 5(5).

Brown, J. (2005). Testing in Language Programs: A Comprehensive Guide to English Language Assessment. New York: McGraw-Hill. https://doi.org/10.1191/02655322051t306xx

Brown, H. (2004). Language Assessment Principles and Classroom Practice. U.S.A: Longman. https://doi.org/10.1080/0969594042000304609

Fleetham, M. (2006). Multiple Intelligences in Practice Enhancing Self-Esteem and Learning in The Classroom, Network Continuum Education.

Liz \& Soars, J. (2010). New Headway Plus: Intermediate Student's Book. Oxford: Oxford Press.

Madkour, M., \& Mohamamed, R. (2016). Identifying College Students' Multiple Intelligences to Enhance Motivation and Language Proficiency. English Language Teaching, 9(6). https://doi.org/10.5539/ elt.v9n6p92 
McKenzie, W. (2002). Multiple Intelligences and Instructional Technology: A Manual For Every Mind. Eugene, OR: International Society for Technology in Education.

Mirzazadeh, M. (2012). Impacts of Multiple Intelligences on Learning English in the ESL Classroom. American Journal of Scientific Research, 60, 64-74.

Naqeeb, H., \& Awad, A. (2011). Learning Styles as Perceived by Learners of English as a Foreign Language in the English Language Center of The Arab American University - Jenin, Palestine. An - Najah Univ. J. Res. (Humanities), 25(8), 2231-2256.

Obinne, A. D. E. (2012). Using IRT in Determining Test Item Prone to Guessing. World Journal of Education, 2(1). https://doi.org/10.5430/wje.v2n1p91

Richards \& Rodgers. (2001). Approaches and Methods in Language Teaching. Cambridge: Cambridge University Press.

Richards, J., \& Schmidt, R. (2002). Dictionary of Language Teaching \& Applied Linguistics (3rd ed.). Pearson Education: London.

Silja, K., \& Viens, J. (2001). Multiple Intelligences in Practice: Teacher Research Reports from the Adult Multiple Intelligences Study.

Tirri, K., \& Nokelainen, P. (2011). Measuring Multiple Intelligences and Moral Sensitivities in Education. Sense Publishers, Rotterdam/Boston/Taipel. https://doi.org/10.1007/978-94-6091-758-5

Torresan, P. E. (2010). The Theory of Multiple Intelligences and Language Teaching.

Williams, M. (1994). Motivation in Foreign and Second Language Learning: An Interactive Perspective. Educational and Child Psychology, 11, 77-84.

\section{Appendix (A)}

\section{Analytic Domain of Multiple -intelligence Questionnaire}

Dear Student

Read each statement quickly and choose one certain word that describes you and definitely applies to you. Remember, the test will only be accurate if you're honest with yourself so complete the test based on what you actually think and feel, not on how you think you should or want to feel. Thank you in advance

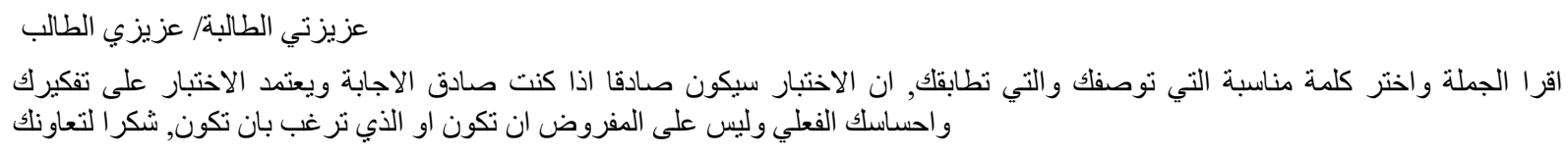

\begin{tabular}{|c|c|c|c|c|c|c|}
\hline No. & Logical/Mathematic & always & Often & Sometimes & Rarely & Never \\
\hline 1 & $\begin{array}{l}\text { I remember facts, figures and formulas easily النكر الحفائق والشكال } \\
\text { والصيخ }\end{array}$ & & & & & \\
\hline 2 & 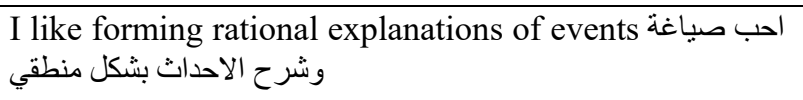 & & & & & \\
\hline 3 & I can do math in my head استطيع عمل الحساب في راسي & & & & & \\
\hline 4 & 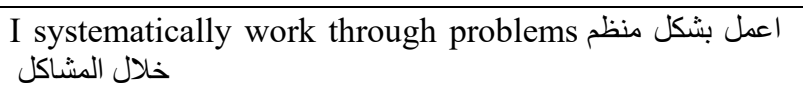 & & & & & \\
\hline & Musical & always & Often & Sometimes & Rarely & Never \\
\hline 5 & $\begin{array}{l}\text { I have always dreamed of being a musician or singer } \\
\text { احلم دائما ان اكون موسيقي او مغني }\end{array}$ & & & & & \\
\hline 6 & $\begin{array}{l}\text { I sing in the shower and often sing to myself اغني لنفسي الحمام } \\
\text { واغني }\end{array}$ & & & & & \\
\hline 7 & 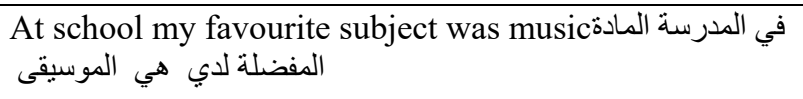 & & & & & \\
\hline 8 & $\begin{array}{l}\text { I would prefer to go to the opera or concert افضل الذهابة الموسيقية } \\
\text { الحفلاب الحفلية }\end{array}$ & & & & & \\
\hline
\end{tabular}




\begin{tabular}{|c|c|c|c|c|c|c|}
\hline & Naturalist & always & Often & Sometimes & Rarely & Never \\
\hline 9 & 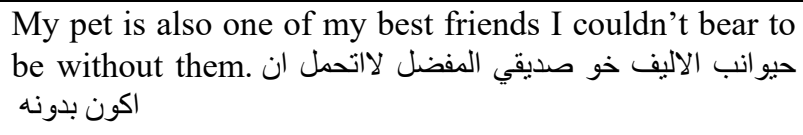 & & & & & \\
\hline 10 & 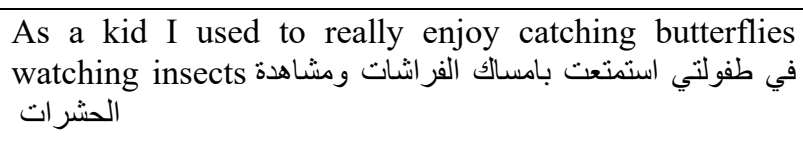 & & & & & \\
\hline 11 & $\begin{array}{l}\text { At school I really enjoyed biology and natural sciences } \\
\text { في المدرسة استمتعت لمو الاحياء والعلوم الطبيعة. اكثر من الجغر اقية }\end{array}$ & & & & & \\
\hline 12 & $\begin{array}{l}\text { I like watching science/nature documentaries تفارير العلوم والطبيعة } \\
\text { احب مشاهدة }\end{array}$ & & & & & \\
\hline
\end{tabular}

\section{Appendix (B)}

\section{English Objective Test}

The internet started in the 1960s. The United States Department of Defense started it because they wanted a computer network to help the American military. In the 1970s, scientists worked on it and learnt how to send messages between computers. Then in the 1980s, telephone companies made it possible to communicate on the computer network in many more countries. An international computer language was born, and the Net went worldwide

Q1- Read the passage, Are the sentences true $(\sqrt{ })$ or false (X)

1-The Internet started in the 1970s.

2- Telephone companies started it

3- It started in America.

4-There is an international computer language.

5- In the 1980s scientists sent messages between computers.

Q2- Choose the correct answer:

1-What's your name? ........name's Annie. (my- our- your-her)

2- I ......two brothers a sister. and (has- have- am- is)

3- Do you live in Dundee? No, I ......(am- am not- do - don't)

4- Ali .......up at 6:00. (get- gets- got- getting)

$5-\mathrm{He}$......the film yesterday. (watch- watches- watched- watching)

Q3- Mach the verbs with their opposites

\begin{tabular}{|l|l|l|l|l|l|}
\hline A & Leave & Love & Win & Start & Buy \\
\hline B & Finish & Sell & Arrive & Lose & Hate \\
\hline
\end{tabular}

Q4- Tick $(\sqrt{ })$ the correct sentence

I'm wear a blue shirt today.

$\bigcirc$ Where are you going.

I'm wearing a blue shirt today

$\bigcirc$ Peter no working this week

Where you going

Why aren't you having a coffee

$\bigcirc$ Peter isn't working this week

I like leave early today

$\bigcirc$ Why you no having a coffee

$\bigcirc$ I'd like to leave early today. 
Q5- Put the words in correct list:

Hotel- bread- cinema- seafood- fish- bank- writer- actor- rice- artist- driver- doctor- chicken -school-- eggscafé- car park- singer-salad-

\begin{tabular}{|l|l|l|}
\hline Places & jobs & Food \\
\hline & & \\
\hline
\end{tabular}

Q6- Re-order the words to make questions:

1- I/ can/ you/ help/?/

2- tell/ time/ me/ ?/ you/ the/ can/

\section{Copyrights}

Copyright for this article is retained by the author(s), with first publication rights granted to the journal.

This is an open-access article distributed under the terms and conditions of the Creative Commons Attribution license (http://creativecommons.org/licenses/by/4.0/). 